\title{
Diet segregation between two colonies of little penguins Eudyptula minor in southeast Australia
}

\author{
ANDRÉ CHIARADIA, ${ }^{1 *}$ MANUELA G. FORERO, ${ }^{2}$ KEITH A. HOBSON, ${ }^{3}$ \\ STEPHEN E. SWEARER, ${ }^{4}$ FIONA HUME, ${ }^{1,5}$ LEANNE RENWICK ${ }^{1}$ AND PETER DANN ${ }^{1}$ \\ ${ }^{1}$ Research Department, Phillip Island Nature Parks, PO Box 97, Cowes,Vic. 3922, Australia (Email: \\ achiaradia@penguins.org.au); ${ }^{2}$ Departamento de Biología de la Conservación, Estación Biológica de \\ Doñana, Avda Américo Vespucio, Sevilla, Spain; ${ }^{3}$ Environment Canada, Saskatoon, Saskatchewan, \\ Canada; ${ }^{4}$ Department of Zoology, University of Melbourne, Melbourne, Victoria, and ${ }^{5}$ Private Bag 10, \\ New Norfolk, Tasmania, Australia
}

\begin{abstract}
We studied foraging segregation between two different sized colonies of little penguins Eudyptula minor with overlapping foraging areas in pre-laying and incubation. We used stomach contents and stable isotope measurements of nitrogen $\left(\mathrm{d}^{15} \mathrm{~N}\right)$ and carbon $\left(\mathrm{d}^{13} \mathrm{C}\right)$ in blood to examine differences in trophic position, prey-size and nutritional values between the two colonies. Diet of little penguins at St Kilda (small colony) relied heavily on anchovy while at Phillip Island (large colony), the diet was more diverse and anchovies were larger than those consumed by St Kilda penguins. Higher $\mathrm{d}^{15} \mathrm{~N}$ values at St Kilda, differences in $\mathrm{d}^{13} \mathrm{C}$ values and the prey composition provided further evidence of diet segregation between colonies. Penguins from each colony took anchovies from different cohorts and probably different stocks, although these sites are only $70 \mathrm{~km}$ apart. Differences in diet were not reflected in protein levels in the blood of penguins, suggesting that variation in prey between colonies was not related to differences in nutritional value of the diet. Anchovy is currently the only available prey to penguins throughout the year and its absence could have a negative impact on penguin food supply, particularly at St Kilda where the diet is dominated by this species. While it is difficult to establish whether diet segregation is caused by inter- or intra-colony competition or spatial differences in foraging areas, we have shown that colonies with broadly overlapping foraging ranges could have significant differences in trophic position, diet composition and prey size while maintaining a diet of similar nutritional value.
\end{abstract}

Key words: $\mathrm{d}^{15} \mathrm{~N}, \mathrm{~d}^{13} \mathrm{C}$, diet, Engraulis australis, Eudyptula minor, fish size-class, stable isotope.

\section{INTRODUCTION}

Strategies to exploit prey are a major selective force determining the breeding success and population structure of seabirds (Ashmole 1971). As central place foragers, seabirds are constrained by availability of prey in a restricted foraging area (Lack 1968) and this can determine the nature and success of their foraging behaviour. Thus, food availability is a major factor limiting seabird populations by regulating breeding success, survival and recruitment (Furness \& Birkhead 1984) and population size (Dann \& Norman 2006).

Adaptation to food availability clearly shapes seabird life history traits but evidence for energy limitation in shaping foraging strategies of seabirds is sparse (see review in Schreiber \& Burger 2001) probably due to the variety of foraging behaviours seabirds use to deal with mobile and patchily distributed prey over vast areas of the ocean. Such foraging behaviours can

*Corresponding author. switch often, even within species, due to changes in prey quality, composition and inter-specific competition (Forero et al. 2002a, 2005; Barrett et al. 2007). Recent studies incorporating trophic segregation, however, have shown that sympatric seabirds forage in different areas, which suggests an evolved mechanism for cohabitation (Navarro et al. 2009). Clearly, a combination of factors could be responsible for the plasticity observed in seabird foraging behaviour (Schreiber \& Burger 2001). Continuing investigations using a variety of tools, especially on the same species in different regions or circumstances will help to elucidate some of these questions.

Intra-specific competition, which likely increases with colony size, can increase foraging effort by individuals (Ballance et al. 2009) and affect breeding output (Shealer 2001). Several studies have demonstrated the effect of colony size on competition for food in seabirds (Shealer 2001; Forero et al. 2005) and the resulting life-history consequences (Schreiber \& Burger 2001; Dann \& Norman 2006). However, fewer studies have examined changes in diet composition 
and trophic interaction among colonies of different size (Forero et al. 2002a, 2005; Barrett et al. 2007).

The little penguin, Eudyptula minor, is a good model species to examine causes and consequences of dietary changes in seabirds. Lack of food seems to be a major threat to little penguins as starvation is likely to be the major cause of adult mortality at sea (Dann 1992; Harrigan 1992; Hobday 1992). As with most seabirds, little penguins are generalist feeders with large variability in diet among colonies and years at the same colony. Little penguins feed on a variety of small fish, cephalopods and crustaceans but mainly on clupeids, such as anchovy (Engraulis spp.) and pilchards (Sardinops sagax) during breeding (Klomp \& Wooller 1988; Gales \& Pemberton 1990; Cullen et al. 1992; Fraser \& Lalas 2004; Chiaradia et al. 2010). This flexibility in diet is also found in their trophic interactions where penguins can reduce their trophic breadth in response to years of low breeding success (Chiaradia et al. 2010). Previous studies have compared diets among colonies with nonoverlapping foraging areas (Gales \& Pemberton 1990; Cullen et al. 1992), but none have examined trophic segregation among colonies with foraging areas that overlap for a significant period of the breeding cycle.

Pilchard was an important clupeoid prey item for little penguins at the study area until 1995 when a massive mortality resulted in the crash of their population across southern Australia and New Zealand (Jones et al. 1997). Since then, the Australian anchovy (Engraulis australis) is the main clupeid in their diet (Chiaradia et al. 2003, 2010). Anchovy is an important species in the diet of top marine predators in southern Australia (Kailola et al. 1993; Hoedt \& Dimmlich 1994; Bunce \& Norman 2000; Chiaradia et al. 2002, 2003) and this species spawns in inshore and bay waters where juveniles stay until maturity (Blackburn 1950). At two years old or more, anchovies move into open waters in winter and return inshore in spring to breed (Kailola et al. 1993). In Port Phillip Bay, Victoria, Australia, anchovies are present year-round and are a major prey for several fish species in the bay (Coutin 2006). Anchovy reach $6-8 \mathrm{~cm}$ in their first year (Blackburn 1950) and therefore remain within the size range of prey consumed by little penguins (mean $=6.5 \mathrm{~cm}, \mathrm{SD}=1.6 \mathrm{~cm}$ calculated from Cullen et al. 1992) for about one year.

Here, we examined whether the diet of little penguins varies between the St Kilda and Phillip Island colonies (Victoria, southeast Australia), which have overlapping foraging ranges at pre-laying and incubation but differ in population size, breeding chronology and foraging behaviour (Fig. 1). The St Kilda colony is much smaller

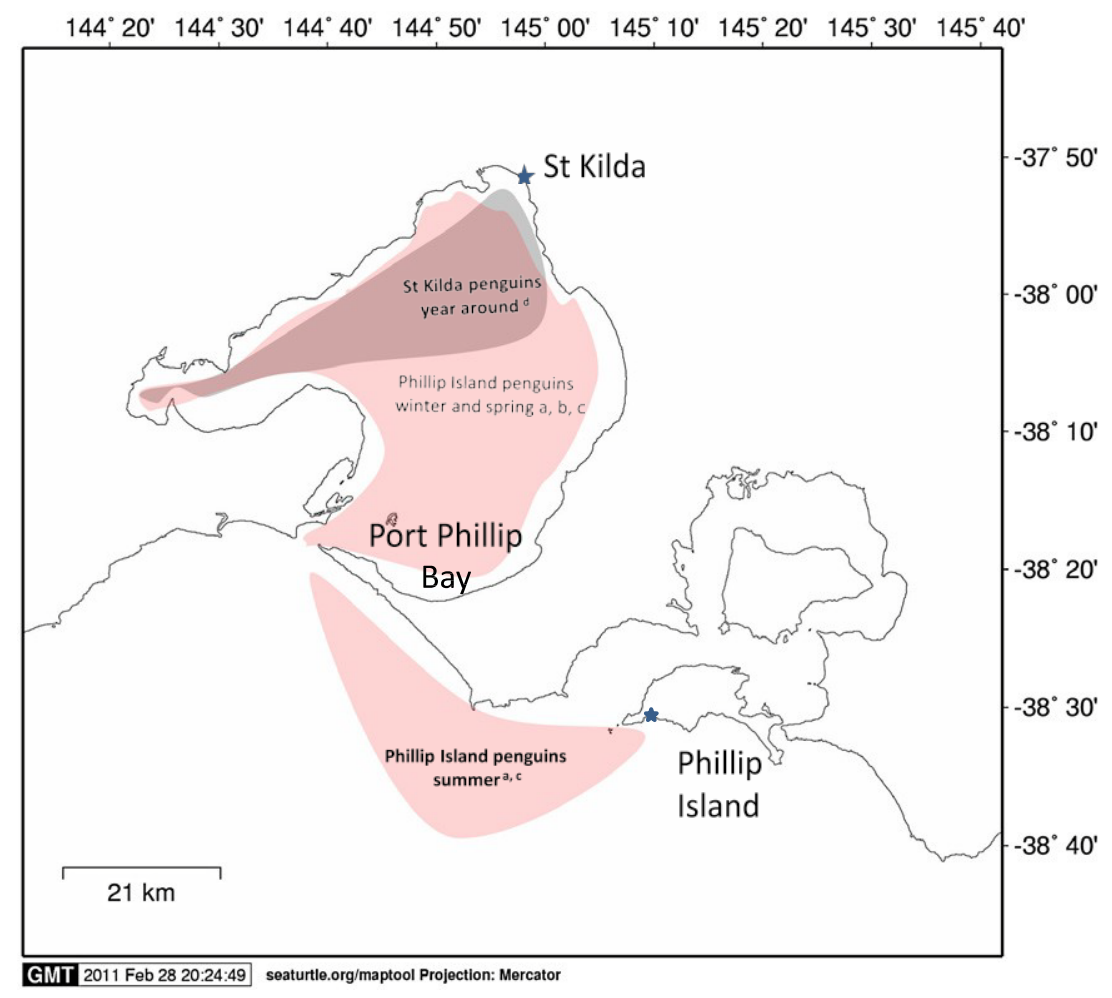

Fig. 1. Location of the two studied colonies. St Kilda is a smaller colony with a foraging area confined to Port Phillip Bay. Phillip Island is a larger colony located $70 \mathrm{~km}$ to the southeast, with the colony facing the ocean side. Foraging areas were adapted from published data for Phillip Island penguins in winter, spring and summer (a, Collins et al. 1999; b, Gormley and Dann 2009; c, Weavers 1992) and for St Kilda over the whole year (d, Preston 2011; Preston et al. 2010). 

( 400 breeding penguins, Preston et al. 2008) than Phillip Island ( 26 000 breeding penguins, Cullen et al. 2009). The foraging area of adult penguins at St Kilda is confined to Port Phillip Bay, a large bay of $1930 \mathrm{~km}^{2}$ in area with waters no deeper than $14 \mathrm{~m}$ (Cullen et al. 1996; Preston et al. 2008), while Phillip Island is surrounded by deeper open waters (Chiaradia et al. 2007). At St Kilda, the penguin foraging area is almost 50\% smaller (Collins et al. 1999; Preston et al. 2008). Most Phillip Island penguins forage inside Port Phillip Bay during laying and incubation stages (Cullen et al. 1996; Collins et al. 1999; McCutcheon et al. 2011), overlapping their foraging area with St Kilda penguins which spend their entire life cycle inside the Bay (Preston et al. 2008, 2010). We used conventional diet analyses (stomach flushing) to examine differences in the importance and composition of prey in the diet of little penguins, in particular anchovy over two breeding periods at both colonies (2003-2004 and 2004-2005). Second, we measured stable isotopes of nitrogen $\left({ }^{15} \mathrm{~N} /\right.$ ${ }^{14} \mathrm{~N}$, measured as $\mathrm{d}^{15} \mathrm{~N}$, see Methods) and carbon $\left({ }^{13} \mathrm{C} /\right.$ ${ }^{12} \mathrm{C}, \mathrm{d}^{13} \mathrm{C}$ ) in the whole blood of adults and chicks to examine potential differences in trophic position (Hobson 2005) and foraging region (Fauchald 2009) during the breeding period (from incubation to chick rearing stage). Third, we determined whether penguins at both colonies were preying on anchovy of similar size. Finally, we compared protein concentrations in the blood of individuals from both colonies as a proxy of body condition (Dawson \& Bortolotti 1997).

\section{METHODS}

This study was carried out at St Kilda (375ㄴ'S, $144^{\circ} 57^{\prime} \mathrm{E}$, Fig. 1) and at the Summerland Peninsula (38 $31^{\prime}$ 'S, $145^{\circ} 07^{\prime} \mathrm{E}$, Fig. 1) on Phillip Island, Australia during the breeding periods of 2003-2004 and 2004-2005, hereafter referred to as the 2003 and 2004 breeding periods. Birds were marked with electronic transponders for individual identification (Trovan, Australia), weighed and sexed by bill measurements (Arnould et al. 2004). Breeding stages such as pre-laying (i.e. 30 days before laying), incubation, chick guard and post-guard (details in Chiaradia \& Kerry 1999) were recorded. Food samples were obtained using a modification of the Gales (1987) stomach-flushing technique (Chiaradia et al. 2003). Samples were frozen at $-18^{\circ} \mathrm{C}$ for later analysis. Each sample was processed according to Gales (1987) and identifications of otoliths, cephalopod beaks and other taxa were based on reference collections described elsewhere (Cullen et al. 1992; Chiaradia et al. 2003). Anchovy otoliths in good condition were removed from the cranium (Gales 1988a) and measured using a digital camera (Panasonic WV-CD50) mounted on a Leitz Orthoplan microscope and connected to a Data Translation DT2867LC frame grabber board in association with BioscanTM (Autoscan Pty Ltd) image analysis software. Otolith length was measured as the distance from the anterior to the posterior margins and used to calculate fish standard length (the distance from the tip of the snout to the base of the caudal fin) using a previously published otolith length : fish length regression equation (Cullen et al. 1992) for this species.

Whole blood samples from penguins were collected from Phillip Island and St Kilda. In each colony, penguins were sampled during the pre-laying, incubation, feeding young chicks (around 3 weeks old, guard stage) and feeding old chicks (post-guard stage between 6 and 7 weeks old, details on chick stages in Chiaradia \& Kerry 1999) breeding stages. In addition to adults, chicks in both guard and post-guard stages were sampled at each site. In all cases, about $0.18 \mathrm{~mL}$ of blood was extracted from the tarsal vein.

Nutritional differences between different seabird species (Newman et al. 1997), ages and sexes (Work 1996), or breeding stages (Mortimer \& Lill 2007) can be assessed by haematological analysis. For instance, total blood protein provides an approximate but adequate method to measure changes in the health of populations (Newman et al. 1997), an approach that has been successfully trialled on little penguins (Mortimer \& Lill 2007). In 2003, part of the blood collected was used to measure total blood protein $\left(\mathrm{g} \mathrm{dL}^{-1}\right)$ as an index to examine any diet-derived nutritional differences between colonies (Work 1996; Newman et al. 1997). We centrifuged blood without ethanol within two hours after collection to measure total plasma protein concentration using a portable refractometer (Dawson \& Bortolotti 1997). For stable isotope analyses, the remaining blood from the 2003 samples and all of the 2004 blood samples were preserved in $70 \%$ ethanol and at room temperature $\left(20-25^{\circ} \mathrm{C}\right)$.

\section{Stable isotope analyses}

Stable nitrogen $\left(\mathrm{d}^{15} \mathrm{~N},{ }^{15} \mathrm{~N} /{ }^{14} \mathrm{~N}\right)$ and carbon $\left.{ }^{13} \mathrm{C} /{ }^{12} \mathrm{C}, \mathrm{d}^{13} \mathrm{C}\right)$ isotope measurements have been used to infer the diets of marine animals (Hobson \& Welch 1992; Forero et al. 2002a, 2005). The value of $d^{15} \mathrm{~N}$, and to a lesser extent $d^{13} \mathrm{C}$, increases with trophic level in relatively predictable increments (Fry 2006). Values of $d^{13} \mathrm{C}$ can also be used to discriminate between pelagic and benthic prey (e.g.Hobson \& Welch 1992; France 1995). Diet data derived from whole blood, used in this study, reflect a period of dietary integration of about 4 weeks in which food was ingested (Bearhop et al. 2002).

Before stable isotope analyses, blood samples were separated from ethanol, freeze-dried and then powdered. Stable-carbon and nitrogen isotope assays were performed on $1 \mathrm{mg}$ of homogenized sample by loading into tin cups and combusting at $1200^{\circ} \mathrm{C}$ in a Robo-Prep elemental analyser. Resultant $\mathrm{CO}_{2}$ and $\mathrm{N}_{2}$ gases were then analysed using an interfaced Europa 20:20 continuous-flow isotope ratio mass spectrometer (CFIRMS) with 2 (BWB baleen and egg albumen) laboratory standards run for every 5 samples. Based on replicate measurements of the within-run standards, we estimate measurement error to be ! $0.3 \%$ and ! $0.1 \%$ or $\mathrm{d}^{15} \mathrm{~N}$ and $\mathrm{d}^{13} \mathrm{C}$ respectively.

We also used published information on stable isotope values of potential prey (Chiaradia et al. 2010; Preston 2011) to compare the trophic position of penguins from the two colonies. Ideally, prey tissue should be collected from stomach contents but at Phillip Island, stomach contents are usually highly digested (Chiaradia et al. 2003), which prevented sampling from non-digested prey. Nevertheless, the prey isotopic values for the main prey, anchovies did not 
differ according to values published for the two sites (Chiaradia et al. 2010; Preston 2011).

\section{Data analysis}

We calculated diet by recording the mass of each prey species relative to the total mass of each stomach sample, hereafter referred to as relative importance of prey. We calculated mean percentage values of each prey per year. The absence of a prey in the sample was recorded as a zero value to prevent overestimation of prey importance and empty stomachs were included. As a consequence, the sum of all species each year did not necessarily reach $100 \%$. By using relative importance of prey, each sample was weighted equally regardless of the biomass of the stomach contents. This method prevents biases towards the chick-rearing stage, when stomach mass is several times heavier than other stages of the penguin's life cycle (Montague \& Cullen 1988; Cullen et al. 1992; Chiaradia et al. 2003). Diet showed no seasonal variation at St Kilda but was quite variable at Phillip Island. Thus, seasonal diet composition was broken down to stages only at Phillip Island. For comparison between the two sites, seasonal diet is only given for anchovies.

We used Generalized Linear Mixed Models (lme4 package, Bates \& Maechler 2009) in R (R Development Core Team 2009) to analyse variability in $d^{15} N$ and $d^{13} C$ values of little penguins from Phillip Island and St Kilda, and tested for the fixed effects of colony (St Kilda and Phillip Island), breeding period (2003 and 2004), sex, breeding stage (incubation, guard and post-guard) and age-class (chicks vs. adults). Repeated measures from the same adult individual between years or among breeding stages were treated as a random term in the model (1/individual, Bates \& Maechler 2009). The main effects of these variables and their interactions were tested in the models. Model selection was based on minimum Akaike Information Criterion values and Akaike weights to select the best fit model (Burnham \& Anderson 2004). The proportion of variation explained by the best fit model was calculated by fitting a null model to estimate the total deviance (Zuur et al. 2009).

Laying dates were converted to Julian days to calculate the effect of year on the mean laying date between the two years. We used GLM model in R (R Development Core Team 2009) for adults and chicks to test for differences in protein levels among colonies, sex (adults) and breeding stages in
2003. Only data from incubation and guard stages were used in this analysis as pre-laying and post-guard data were not available for St Kilda.

\section{RESULTS}

We identified 17 species of fish, five cephalopods and three species of crustaceans in the stomach samples of little penguins from both colonies combined (Appendix S1). At St Kilda, two prey species combined comprised $60-80 \%$ (2003 and 2004, respectively) of the total relative prey importance in the diet. Anchovy dominated the diet of penguins at St Kilda, with relative prey importance of $47 \%$ in 2003 to $78 \%$ in 2004. Luminous bay squid (Loliolus noctiluca) was the second most common prey at St Kilda but with a much lower presence than anchovy (Appendix S1). At Phillip Island, the diet was more diverse with barracouta (Thyrsites atun) as the most common prey while krill (Nyctiphanes australis) and arrow squid (Nototodarus gouldi) alternated as the second-most common prey in 2003 and 2004, respectively (Table 1). Anchovy was the third most important prey in the diet in both years (Table 1).

Anchovy was the only major prey in common between the two colonies (Appendix S1). As detailed seasonal change in the diet of little penguins from Phillip Island has been published elsewhere (Chiaradia et al. 2003) we focused our seasonal analysis on anchovies. While the importance of anchovy was unchanged during the breeding period at St Kilda (Table 1), its importance at Phillip Island increased in the penguin's diet during the breeding period $\left(F_{2,110}=5.48, P=0.01\right.$, Fig. 2). Anchovy was absent at the pre-laying stage (data only for 2003) and appeared in the diet at incubation (only in 2003) with similar importance in relation to the guard stage (Tukey's post-hoc test, $P=$ 0.93). Anchovy was present at guard and post-guard stages in both years at Phillip Island when its importance increased significantly at the post-guard stage of breeding (Tukey's post-hoc test, $P=0.02$, interaction year ¥ breeding stage $F_{2,110}=1.01, P=0.37$, Fig. 2).

Table 1. Diet composition of little penguins at Phillip Island and St Kilda during the 2003 and 2004 breeding periods

\begin{tabular}{|c|c|c|c|c|c|}
\hline \multirow[b]{2}{*}{ Class } & \multirow[b]{2}{*}{ Species } & \multicolumn{2}{|c|}{ Phillip Island } & \multicolumn{2}{|c|}{ St Kilda } \\
\hline & & $2003(80)$ & $2004(50)$ & $2003(26)$ & $2004(47)$ \\
\hline \multirow[t]{2}{*}{ Fish } & Anchovy Engraulis australis & $9 \%$ & $12 \%$ & $47 \%$ & $78 \%$ \\
\hline & Other fish & $60 \%$ & $56 \%$ & $8 \%$ & $9 \%$ \\
\hline \multirow[t]{2}{*}{ Cephalopods } & Arrow squid Nototodarus gouldi & $7 \%$ & $13 \%$ & $4 \%$ & $3 \%$ \\
\hline & Other cephalopods & $8 \%$ & $3 \%$ & $9 \%$ & $10 \%$ \\
\hline \multirow[t]{2}{*}{ Crustaceans } & Krill Nyctiphanes australis & $14 \%$ & $4 \%$ & - & - \\
\hline & Other crustaceans & $1 \%$ & $4 \%$ & - & - \\
\hline
\end{tabular}

Percentage values are mean relative importance of main prey plus the sum other species per taxonomic class. Sample size is in brackets in the column header for each colony and year. A full table with mean values and standard deviation for all species is available as supplement on the online version. 
Penguins from Phillip Island consumed larger anchovies (mean $=9.6$ 【SD $12 \mathrm{~cm}$ ) than penguins from St Kilda (mean $=7.1$ ! SD $11 \mathrm{~cm}, t_{4075}=30.1$, $P<0.001$, Fig. 3). This pattern was consistent for the two years studied (Fig. 3).

In the best fit model for $\mathrm{d}^{15} \mathrm{~N}$, location explained most of the variance in the data for adults (32\% of explained deviance), chicks (60\%) and adults combined with chicks (36\%). St Kilda penguins showed higher $\mathrm{d}^{15} \mathrm{~N}$ values than individuals from Phillip Island (Table 2, Fig. 4). When both colonies were considered separately, breeding stage was the most significant factor included in the model (57\%) at Phillip Island and to a lesser extent at St Kilda (23\%). For St Kilda,

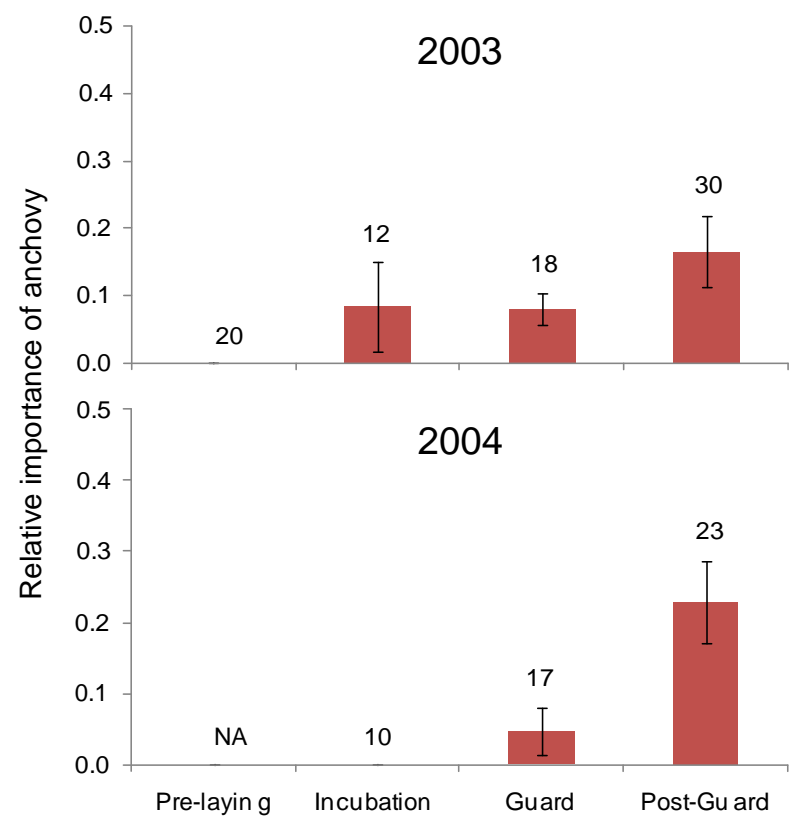

Fig. 2. Relative importance of anchovy in the diet of little penguins at different breeding stages in 2003 and 2004 at Phillip Island. Bars are standard error with number of penguin stomach sampled on top. Note that no data were available for the pre-laying stage in 2004 . segregation in $\mathrm{d}^{15} \mathrm{~N}$ between chicks and adults was higher (19\%) than for Phillip Island (3\%). Although significant, the factor 'year' explained little of the variation in $\mathrm{d}^{15} \mathrm{~N}$ for either colonies (Table 3).

Location was also the most important predictor of variation in $\mathrm{d}^{13} \mathrm{C}$ of chicks (96\%) but was not significant for adults (Table 3). For adults at both colonies, breeding stage (factor Stage) explained $36 \%$ of the

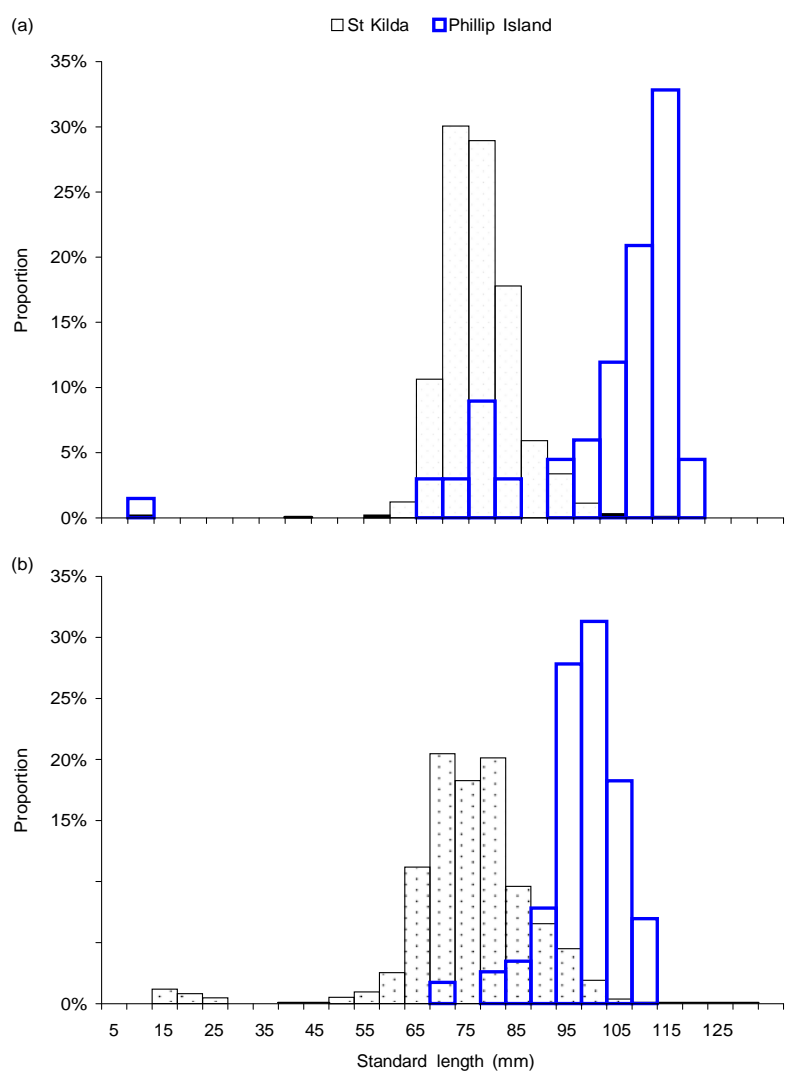

Fig. 3. Proportion of size-classes (standard length) for anchovies preyed on by little penguins from Phillip Island and St Kilda during the (a) 2003 and (b) 2004 breeding periods.

Table 2. Mean stable isotope values (\%, SD, $n)$ for nitrogen $\left(\mathrm{d}^{15} \mathrm{~N}\right)$ and carbon $\left(\mathrm{d}^{13} \mathrm{C}\right)$ in the blood of little penguins at St Kilda and Phillip Island

\begin{tabular}{|c|c|c|c|c|}
\hline \multirow[b]{2}{*}{ Breeding stage } & \multicolumn{2}{|c|}{ Phillip Island } & \multicolumn{2}{|c|}{ St Kilda } \\
\hline & $\mathrm{d}^{15} \mathrm{~N}$ & $d^{13} \mathrm{C}$ & $\mathrm{d}^{15} \mathrm{~N}$ & $\mathrm{~d}^{13} \mathrm{C}$ \\
\hline Pre-laying & $15.1(1,44)$ & $-18.9(0.5,44)$ & $17.7(1.7,3)^{\dagger}$ & $-19.3(0.3,3)^{\mathrm{a}}$ \\
\hline Incubation & $15.8(0.5,40)$ & $-19.2(0.3,40)$ & $18.6(0.7,7)$ & $-19.3(0.4,7)$ \\
\hline Guard & $15.4(0.2,32)$ & $-19.8(0.2,32)$ & $18.6(0.3,8)$ & $-19.4(0.3,8)$ \\
\hline Post-guard & $14.5(0.2,35)$ & $-19.9(0.2,35)$ & - & - \\
\hline Young chicks & $14.9(0.3,41)$ & $-20.1(0.2,41)$ & $18.0(0.5,11)$ & $-19.5(0.3,11)$ \\
\hline Old chicks & $14.8(0.3,39)$ & $-20.0(0.3,39)$ & $17.6(1, \quad 16)$ & $-19.4(0.2,16)$ \\
\hline
\end{tabular}

Since there was no effect of year in the analysis (see text), data from 2003 and 2004 were pooled. Note that at St Kilda, data were not available for the post-guard stage $(-)$. ${ }^{\dagger}$ Data for the pre-laying stage at St Kilda were only available in 2003. 


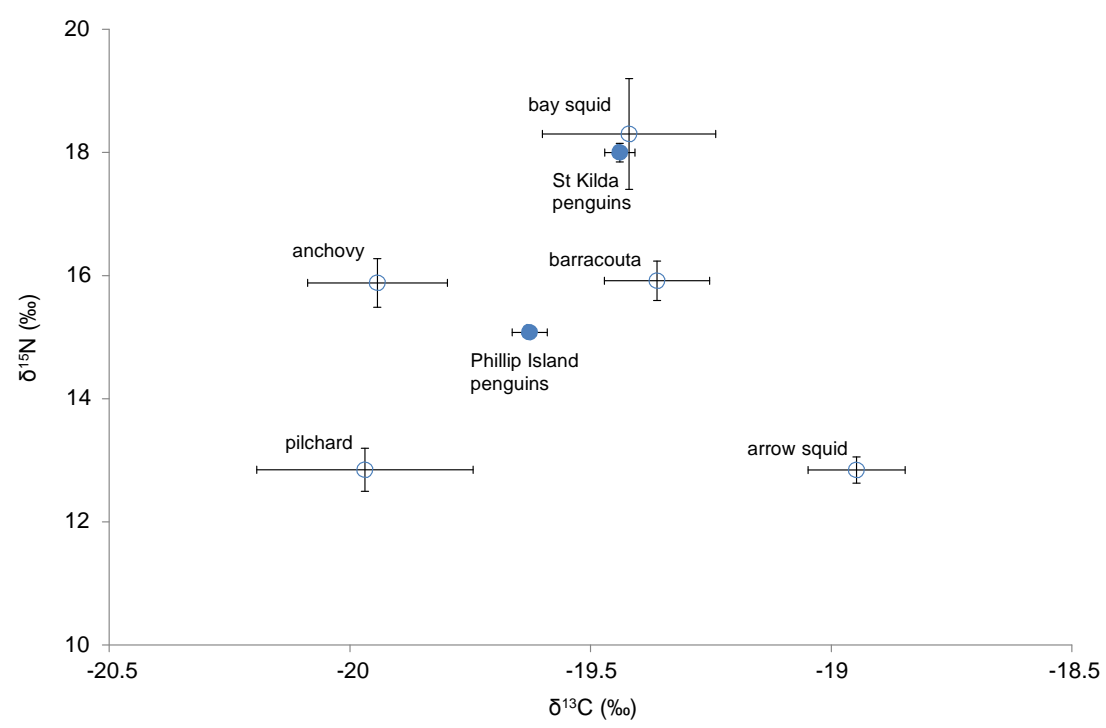

Fig. 4. Overall isotope values of nitrogen and carbon of little penguins at St Kilda and Phillip Island in 2003 and 2004 , and prey values for anchovy, barracouta, pilchard and arrow squid from Chiaradia et al. (2010) and luminous bay squid from Preston (2011).

Table 3. Generalized linear mixed models (GLMMs) or generalized linear models (GLMs) with individual bird as a random factor (1/ID)

\begin{tabular}{|c|c|c|c|c|c|c|}
\hline \multirow{3}{*}{$\begin{array}{l}\begin{array}{l}\text { Response } \\
\text { variable }\end{array} \\
\mathrm{d}^{15} \mathrm{~N}\end{array}$} & \multicolumn{2}{|c|}{ Model } & Best fit models & \multirow{2}{*}{$\begin{array}{c}\text { AICc } \\
280.3\end{array}$} & \multirow{2}{*}{$\begin{array}{c}\begin{array}{c}\text { Explained } \\
\text { deviance }\end{array} \\
42 \%\end{array}$} & \multirow{2}{*}{$\begin{array}{c}\begin{array}{c}\text { Akaike } \\
\text { weights }\end{array} \\
0.56\end{array}$} \\
\hline & Adults & GLMM & d15N $\sim$ Location + Year + Stage $+(1 \mid$ ID $)$ & & & \\
\hline & & & $\mathrm{d} 15 \mathrm{~N} \sim$ Location $¥$ Stage + Year + (1|ID) & 281.2 & $43 \%$ & 0.36 \\
\hline & & & $\begin{array}{l}\mathrm{d} 15 \mathrm{~N} \sim \text { Year }+ \text { Stage }+(1 \mid \mathrm{ID}) \text { (without } \\
\quad \text { Location) }\end{array}$ & 436.2 & $2 \%$ & 0.00 \\
\hline & Chicks & GLMM & d15N $\sim$ Location $¥$ Year $¥$ Stage $+(1 \mid$ ID $)$ & 114.9 & $69 \%$ & 0.86 \\
\hline & & & d15N $\sim$ Location $¥$ Year + (1|ID) & 156.4 & $64 \%$ & 0.12 \\
\hline & $\begin{array}{l}\text { Adults vs. } \\
\text { chicks }\end{array}$ & GLMM & $\begin{array}{l}\text { d15N Location + Year + Stage + Sex } \\
\quad+(1 \mid \text { ID })\end{array}$ & 461.8 & $49 \%$ & 0.80 \\
\hline & & & d15N $\sim$ Location $¥$ Year $¥$ Age + (1|ID) & 464.6 & $47 \%$ & 0.20 \\
\hline & Phillip & GLM & d15N $\sim$ Age $¥$ Year $¥$ Stage $+(1 \mid$ ID) & 17.8 & $64 \%$ & 0.66 \\
\hline & Island & & d15N $\sim$ Age + Year + Stage + (1|ID) & 19.1 & $62 \%$ & 0.34 \\
\hline & St Kilda & GLM & d15N $\sim$ Age $¥$ Year $¥$ Stage $+(1 \mid$ ID $)$ & 80.9 & $40 \%$ & 0.33 \\
\hline & & & d15N $\sim$ Age + Year + Stage + (1|ID) & 82.5 & $29 \%$ & 0.15 \\
\hline & & & d15N $\sim$ Age $+(1 \mid$ ID $)$ & 83.3 & $19 \%$ & 0.10 \\
\hline & & & d15N $\sim$ Stage $+(1 \mid$ ID $)$ & 83.6 & $23 \%$ & 0.09 \\
\hline & & & $\mathrm{d} 15 \mathrm{~N} \sim$ Year + (1|ID) & 88.2 & $7 \%$ & 0.01 \\
\hline \multirow[t]{7}{*}{$\mathrm{d}^{13} \mathrm{C}$} & Adults & GLMM & $\begin{array}{l}\text { d13C } \sim \text { Location + Sex + Year + Stage } \\
\quad+(1 \mid \text { ID })\end{array}$ & 137.4 & $49 \%$ & 0.50 \\
\hline & & & d13C Year + Stage + (1|ID) & 137.5 & $44 \%$ & 0.47 \\
\hline & Chicks & GLMM & d13C $\sim$ Location + (1|ID) & 14.4 & $96 \%$ & 0.99 \\
\hline & $\begin{array}{l}\text { Adults vs. } \\
\text { chicks }\end{array}$ & GLMM & $\begin{array}{l}\text { d13C Location + Sex + Year + Age } \\
\quad+(1 \mid \text { ID })\end{array}$ & 298.0 & $33 \%$ & 0.99 \\
\hline & $\begin{array}{l}\text { Phillip } \\
\text { Island }\end{array}$ & GLM & d13C Age $¥$ Year $¥$ Stage $+(1 \mid$ ID $)$ & -35.3 & $30 \%$ & 0.99 \\
\hline & St Kilda & GLM & d13C $\sim$ Age $¥$ Year $¥$ Stage $+(1 \mid$ ID $)$ & 7.4 & $33 \%$ & 0.43 \\
\hline & & & d13C $\sim$ Age + Year + Stage + (1|ID) & 7.1 & $25 \%$ & 0.51 \\
\hline
\end{tabular}

Models have tested for the effect of colony location (Phillip Island and St Kilda), year (2003 and 2004), age-class (adult or chick), sex and breeding stage (see Methods) on stable isotope $\mathrm{d}^{15} \mathrm{~N}$ and $\mathrm{d}^{13} \mathrm{C}$ of little penguin blood at Phillip Island and St Kilda. The models presented were the most supported models based on Akaike Information Criterion (AICc) scores and Akaike weights. 
variation in $\mathrm{d}^{13} \mathrm{C}$ values (Table 3 ). There were differences in $\mathrm{d}^{13} \mathrm{C}$ between chicks and adults at Phillip Island (15\%) but not at St Kilda (Table 3). Sex had no effect $(<1 \%)$ on stable isotope values for both adults and chicks.

The start of breeding varied among seasons and colonies but penguins from St Kilda started earlier in both years (anova, $F_{1,402}=28.76, \quad P<0.001$, Fig. 5) although the difference between colony mean values was higher in 2003 (34 days) than 2004 (13 days) as showed by the interaction in the model: location $¥$ season (anova, $F_{1,402}=5.34, P=0.02$, Fig. 5). St Kilda had longer laying stage than Phillip Island in both years (variance values of 1975 vs. 371, respectively, $P<0.001)$. Thus, even though St Kilda penguins bred earlier, their breeding season overlapped with penguins from Phillip Island (Fig. 5).
Variation in diet between colonies did not translate into differences in penguin blood protein levels. There were no differences in protein values between colonies (Table 4). At Phillip Island, the protein values were higher at pre-laying for females $\left(F_{3,138}=2.68, \quad P=\right.$ 0.05 ) but with no differences in the other stages of breeding (Table 4).

\section{DISCUSSION}

We studied the diet of little penguins from two colonies which differ in population size, foraging range and diving depth (Cullen et al. 1996, 2009; Chiaradia et al. 2007; Preston et al. 2008). The diet composition was similar at both colonies but with different proportions of individual prey. At St Kilda, penguins relied heavily

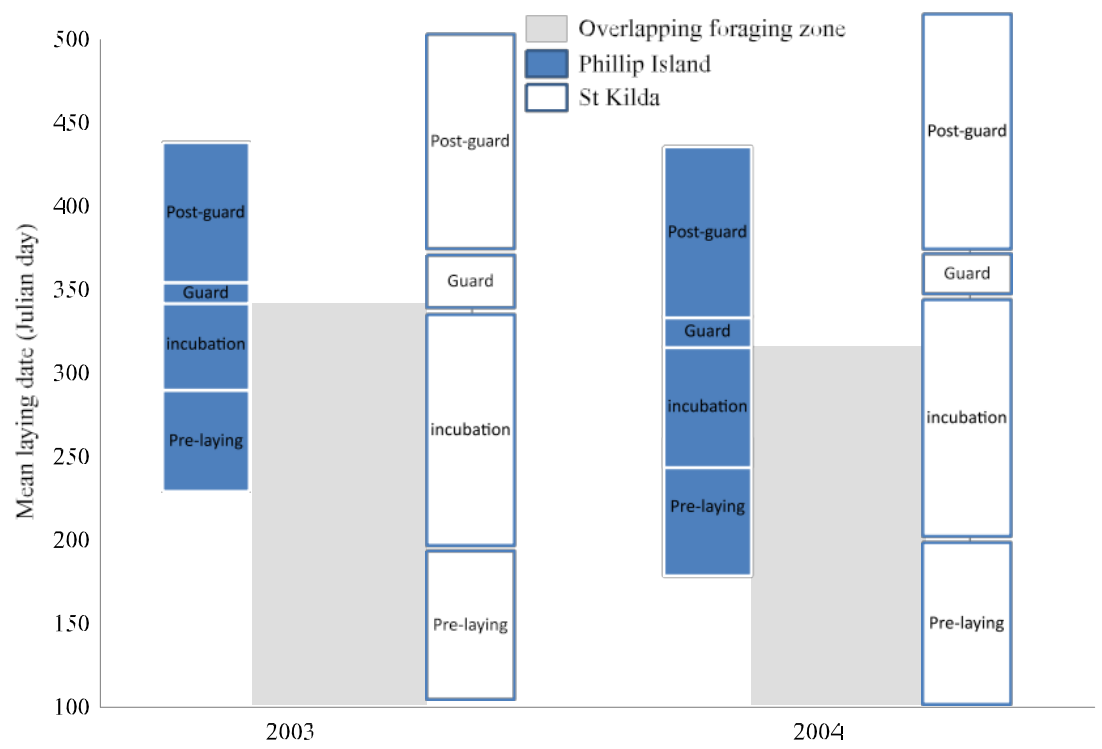

Fig. 5. Breeding cycle of little penguins at Phillip Island and St Kilda in 2003 and 2004 based on the mean laying dates and standard deviations to represent the length of each breeding stage (Chiaradia \& Kerry 1999). Phillip Island penguins bred later than St Kilda in both years but with overlapping breeding season because of the higher standard deviation at St Kilda. The period when penguins from Phillip Island forage inside Port Phillip Bay at pre-laying and incubation (Collins et al. 1999), overlapping with St Kilda penguins is indicated by the grey shading.

Table 4. Protein levels in the blood of little penguins from Phillip Island and St Kilda in 2003

\begin{tabular}{lccccc}
\hline Breeding stage & St Kilda & Phillip Island & Colony location & Sex & Stage \\
\hline Pre-laying & - & $8.1(1.5,30)$ & - & - & - \\
Incubation & $6.8(0.5,3)$ & $6.9(0.9,30)$ & $t=0.3, P=0.75$ & $t=0.1, P=0.92$ & - \\
Guard & $7.1(0.8,4)$ & $7.2(0.9,26)$ & - & - & $\boldsymbol{t}=\mathbf{2 . 6 ,} \boldsymbol{P}=\mathbf{0 . 0 1}$ \\
Post-guard & - & $6.8(0.7,28)$ & $t=1.0, P=0.33$ & - \\
Young chicks & $6.5(0.5,6)$ & $6.4(0.7,31)$ & & \\
Old chicks & $7.1(1.1,8)$ & $6.8(0.7,30)$ & & & \\
\hline
\end{tabular}

Mean values are in $\mathrm{g} \mathrm{dL}^{-1}(\mathrm{SD}, n)$. Using GLM models for adults and chicks (in grey), we found no significant differences in protein levels between colonies, sex (adults only) and breeding stages. Old chicks had higher values than young chicks (in bold) but no differences between colonies. Note that for St Kilda, there were no data for pre-laying and post-guard breeding stages and were therefore excluded in the statistical analysis. 
on anchovy while at the larger Phillip Island colony, diet was much more diverse. We found that Phillip Island penguins bred later than St Kilda penguins in both years. However, St Kilda penguins had a more prolonged laying period so both colonies had an overlapping foraging area when Phillip Island penguins were at pre-laying and incubation stages (Collins et al. 1999; Preston et al. 2010; McCutcheon et al. 2011). Despite sharing the foraging area, little penguins from Phillip Island did not feed on anchovies when their foraging area overlapped with St Kilda penguins. Thus, anchovies were common prey for both colonies but at different times of the year. Although anchovy were not the overall dominant prey at Phillip Island, they appeared in the diet at incubation and reached the highest values at the post-guard stage, when energy requirements for egg production and chick development are at their peak (Astheimer \& Grau 1985; Chiaradia \& Nisbet 2006). Diet segregation between colonies was also detected in trophic values inferred from stable isotope analyses. Consistently, the St Kilda penguins had higher blood $\mathrm{d}^{15} \mathrm{~N}$ values than those from Phillip Island while $\mathrm{d}^{13} \mathrm{C}$ values did not differ between adults from the two colonies.

The higher trophic position of penguins at St Kilda may be partially due to a diet based on anchovy and to a lesser extent on luminous bay squid, both with high $\mathrm{d}^{15} \mathrm{~N}$ values. Anchovies can switch from phytoplankton to zooplankton depending on prey availability (Kimmerer 2006) or even prey on fish eggs and larvae (Mketsu 2008; van der Lingen et al. 2009). As high $\mathrm{d}^{15} \mathrm{~N}$ values are typical of piscivorous species, this suggests that anchovy were also preying on fish eggs and larvae within Port Phillip Bay (Chiaradia et al. 2010). Phillip Island penguins also fed on barracouta, another prey with high $\mathrm{d}^{15} \mathrm{~N}$ values, but also consumed species with low $\mathrm{d}^{15} \mathrm{~N}$ values such as krill and arrow squid (Chiaradia et al. 2010), resulting in a lower trophic position than penguins at St Kilda.

If little penguins were subject to density dependent energy limitation (Lack 1968; Ashmole 1971) during breeding, we would expect poorer diet around the larger colony. In a diet study of crested tern (Thalasseus bergii) breeding at Phillip Island and Port Phillip Bay, Weller (2007) found that the prey of terns were in better condition (and therefore likely greater nutritional value) around Phillip Island, which coincided with mass immigration of terns from Port Phillip Bay to Phillip Island. However, penguins may not be affected in the same way as crested terns. Little penguins dive deeper and explore a foraging area twice as large as terns (Hulsman 1977; Collins et al. 1999; Chiaradia et al. 2007; Weller 2007), which could buffer differences in food availability and quality between the two colonies. Whether diet was related to breeding success at the two colonies could not be examined in this study as breeding success was unknown at St Kilda. However, large seabird colonies have greater food requirements during breeding (Forero et al. 2002b), which could lead to energy limitations during crucial stages of breeding such as incubation and chick-rearing (Gales 1988b) due to lower per capita prey availability in comparison to small colonies (Klasing 1998; Mortimer \& Lill 2007). Nevertheless, it seems that differences in prey composition and diversity did not result in lower total protein reserves in the blood of penguins from the larger colony (Phillip Island).

Anchovies, the only major prey common at both colonies, are prone to large fluctuations in abundance and often exhibit genetic structuring over small geographic scales (Ward et al. 1998). Consequently, knowledge of their population dynamics within stocks is important for providing better understanding and management of this ecologically and commercially important species. As there is scarce information on anchovy stocks in northern Bass Strait (but see Blackburn 1950), the results of our study question whether anchovies are sourced from the same population at both colonies. Penguins from Phillip Island were feeding on anchovies when they were outside Port Phillip Bay (Collins et al.1999), when foraging areas do not overlap between the two colonies. If juvenile anchovy migrate from enclosed bays and inlets to coastal waters of Bass Strait as they mature like they do in South Australia (Dimmlich et al. 2004), penguins from Phillip Island could be feeding on older anchovies from the same cohort that were consumed by St Kilda penguins in Port Phillip Bay earlier in the year. However, the mean size difference of anchovy was $2.5 \mathrm{~cm}$ between the two colonies which represents more than one year of growth (Blackburn 1950). In addition, differences in blood $\mathrm{d}^{13} \mathrm{C}$ were highly significant between chicks of both colonies, indicating that there were spatial differences in the prey taken for chicks between colonies. Thus, we suggest that, when sourcing food for their chicks, Phillip Island and St Kilda penguins are preying on anchovies from at least different cohorts and potentially different stocks, even though the sites are only $70 \mathrm{~km}$ apart. Because of changes in the marine food web of penguins after the pilchard mortality in 1995 (Chiaradia et al. 2010), anchovy is currently the only available prey to penguins throughout the year and its absence could have a negative impact on the penguin's food supply at Phillip Island and, to a larger extent, at St Kilda where penguins are more reliant on anchovy as prey. Future studies on the structure of anchovy stocks are needed to better assess the consequences for these dietary changes for the long-term viability of little penguin colonies in Victoria.

We have shown that little penguin colonies close together with overlapping foraging ranges have significant segregation in composition, prey size and trophic position while maintaining a diet of similar nutritional value. While it is difficult to establish whether diet 
segregation between colonies with different sizes was driven by prey depletion at the larger colony, a task beyond the scope of this paper, our results offer no support to the energy limitation hypothesis of Ashmole (1971).

\section{ACKNOWLEDGEMENTS}

We are grateful for the support of EarthCare, in particular Zöe Hogg and Tiana Preston. We thank M. Healy for providing fish-shake. Stable isotope samples were prepared in the Environment Canada laboratory of $\mathrm{KAH}$ and analysed at the Department of Soil Science, University of Saskatchewan by M. Stocki. We are also grateful for grants received from Penguin Foundation and Junta Andalucía to AC, Ministerio de Educación y Ciencia de España CGL 2006-278999E/BOS to MGF, and additional funding provided by an operating grant to $\mathrm{KAH}$ from Environment Canada. The project was approved by the Phillip Island Nature Park Animal Experimentation Ethics Committee and by the Department of Sustainability and Environment of Victoria, Australia. We dedicate this paper to Professor Gary Bortolotti who sadly and prematurely left us this year.

- Map created using SEATURTLE.ORG's Maptool from http://www.seaturtle.org/maptool/.

\section{REFERENCES}

Arnould J. P.Y., Dann P. \& Cullen J. M. (2004) Determining the sex of little penguins (Eudyptula minor) in northern Bass Strait using morphometric measurements. Emu 104, 261-5.

Ashmole N. P. (1971) Sea bird ecology and the marine environment. In: Avian Biology (eds D. S. Farner \& J. R. King) pp. 223-86. Academic Press, London.

Astheimer L. B. \& Grau C. R. (1985) The timing and energetic consequences of egg formation in the Adélie penguin. Condor 87, 256-68.

Ballance L. T., Ainley D. G., Ballard G. \& Barton K. (2009) An energetic correlate between colony size and foraging effort in seabirds, an example of the Adélie penguin Pygoscelis adeliae. J. Avian Biol. 40, 279-88.

Barrett R. T., Camphuysen K. C. J., Anker-Nilssen T. et al. (2007) Diet studies of seabirds: a review and recommendations. ICES J. Mar. Sci. 64, 1675-91.

Bates D. \& Maechler M. (2009) lme4: linear mixed-effects models using S4 classes. $R$ package version 0.999375-31. [Cited 7 November 2011.] Available from URL: http:// CRAN.R-project.org/package=lme4

Bearhop S., Waldron S., Votier S. C. \& Furness R. W. (2002) Factors that influence assimilation rates and fractionation of nitrogen and carbon stable isotopes in avian blood and feathers. Physiol. Biochem. Zool. 75, 451-8.

Blackburn M. (1950) A biological study of the anchovy, Engraulis australis (White), in Australian waters. Aust. J. Mar. Freshwater Res. 1, 3-84.

Bunce A. \& Norman F. I. (2000) Changes in the diet of the Australian gannets Morus serrator in response to the 1998 mortality of pilchards Sardinops sagax. Mar. Freshwater Res. 51, 349-52.
Burnham K. P. \& Anderson D. R. (2004) Multimodel inference: understanding AIC and BIC in Model Selection. Sociol. Methods Res. 33, 261-304.

Chiaradia A. \& Nisbet I. C. T. (2006) Plasticity in parental provisioning and chick growth in little penguins Eudyptula minor in years of high and low breeding success. Ardea 94, 257-70.

Chiaradia A., Dann P., Jessop R. \& Collins P. (2002) The diet of Crested Tern, Sterna bergii, chicks on Phillip Island, Victoria. Ети 102, 367-71.

Chiaradia A., Costalunga A. \& Kerry K. (2003) The diet of little penguins Eudyptula minor at Phillip Island, Victoria, following the 1995 mass mortality of one of their main prey, the pilchard Sardinops sagax. Emu 103, 43-8.

Chiaradia A., Ropert-Coudert Y., Kato A., Mattern T. \& Yorke J. (2007) Diving behaviour of little penguins from four colonies across their whole distribution range: bathymetry affecting diving effort and fledging success. Mar. Biol. 151, 1535-42.

Chiaradia A., Forero M. G., Hobson K. A. \& Cullen J. M. (2010) Changes in diet and trophic position of a top predator ten years after a mass mortality of a key prey. ICES J. Mar. Sci. 67, 1710-20.

Chiaradia A. F. \& Kerry K. R. (1999) Nest attendance and breeding success in the little penguins Eudyptula minor at Phillip Island, Australia. Mar. Ornithol. 27, 13-20.

Collins M., Cullen J. M. \& Dann P. (1999) Seasonal and annual foraging movements of little penguins from Phillip Island, Victoria. Wildl. Res. 26, 705-21.

Coutin P. C. (2006) Australian anchovy Engraulis australis: a literature review. Marine and Freshwater Systems Report Series No 14. Primary Industry Research Victoria, Queenscliff.

Cullen J. M., Montague T. L. \& Hull C. (1992) Food of little penguins Eudyptula minor in Victoria: comparison of three localities between 1985 and 1988. Етu 91, 318-41.

Cullen J. M., Chambers L. E., Dann P. \& Coutin P. C. (2009) Predicting the onset and success of breeding of little penguins Eudyptula minor, on Phillip Island from ocean temperatures off south east Australia. Mar. Ecol.Prog. Ser. 378, 269-78.

Cullen M., Blake N. \& Bickham M. (1996) Urban penguins. In: Nature Australia (ed. G. Hickey) pp. 23-8. Australian Museum, Sydney.

Dann P. (1992) Distribution, population trends and factors influencing the population size of little penguins Eudyptula minor on Phillip Island, Victoria. Еmu 91, 263-72.

Dann P. \& Norman F. I. (2006) Population regulation in little penguins (Eudyptula minor): the role of intraspecific competition for nesting sites and food during breeding. Етu 106, 289-96.

Dawson R. D. \& Bortolotti G. R. (1997) Total plasma protein level as an indicator of condition in wild American kestrels (Falco sparverius). Can. J. Zool. 75, 680-6.

Dimmlich W. F., Breed W. G., Geddes M. \& Ward T. M. (2004) Relative importance of gulf and shelf waters for spawning and recruitment of Australian anchovy, Engraulis australis, in South Australia. Fisheries Oceanogr. 13, 310-23.

Fauchald P. (2009) Spatial interaction between seabirds and prey: review and synthesis. Mar. Ecol. Prog. Ser. 391, 13951.

Forero M. G., González-Solís J., Hobson K. A. et al. (2005) Stable isotopes reveal trophic segretation by sex and age in the southern giant petrel in two different food webs. Mar. Ecol. Prog. Ser. 296, 107-13.

Forero M. G., Hobson K. A., Bortolotti G. R., Donázar J. A., Bertellotti M. \& Blanco G. (2002a) Food resource utilisation by the Magellanic penguin evaluated through stable- 
isotope analysis: segregation by sex and age and influence on offspring quality. Mar. Ecol.Prog. Ser. 234, 289-99.

Forero M. G., Tella J. L., Hobson K. A., Bertellotti M. \& Blanco G. (2002b) Conspecific food competition explains variability in colony size: a test in Magellanic penguins. Ecology 83, 3466-75.

France R. L. (1995) Carbon-13 enrichment in benthic compared to planktonic algae: foodweb implications. Mar. Ecol. Prog. Ser. 124, 307-12.

Fraser M. M. \& Lalas C. (2004) Seasonal variation in the diet of blue penguins Eudyptula minor at Oamaru, New Zealand. Notornis 51, 7-15.

Fry B. (2006) Stable Isotope Ecology. Springer, New York.

Furness R. W. \& Birkhead T. R. (1984) Seabird colony distributions suggest competition for food supplies during the breeding season. Nature 311, 655-6.

Gales R. P. (1987) Validation of the stomach-flushing technique for obtaining stomach contents of penguins. Ibis 129, 335-43.

Gales R. P. (1988a) The use of otoliths as indicators of little penguin Eudyptula minor diet. Ibis 130, 418-26.

Gales R. P. (1988b) Water, sodium and energy turnover in free-living little penguins, Eudyptula minor. Aust. J. Zool. 36, 429-40.

Gales R. P. \& Pemberton D. (1990) Seasonal and local variation in the diet of the little penguin, Eudyptula minor, in Tasmania. Aust. J.Wildl. Res. 17, 231-59.

Gormley A. M. \& Dann P. (2009) Examination of little penguin winter movements from satellite tracking data. Report: Department of Sustainability and Environment, Victoria.

Harrigan K. E. (1992) Causes of mortality of little penguins Eudyptula minor in Victoria. Eтu 91, 273-7.

Hobday D. K. (1992) Abundance and distribution of pilchard and Australian anchovy as prey species for the little penguin Eudyptula minor at Phillip Island, Victoria. Eтu 91, 342-54.

Hobson K. A. (2005) Stable isotopes and the determination of avian migratory connectivity and seasonal interactions. Auk 122, 1037-48.

Hobson K. A. \& Welch H. E. (1992) Determination of trophic relationships within a high Arctic marine food web using

13C and 15N analysis. Mar. Ecol.Prog. Ser. 84, 9-18. Hoedt F. E. \& Dimmlich W. F. (1994) Diet of subadult Australian salmon, Arripis truttaceus, in Western Port, Victoria. Aust. J. Mar. Freshwater Res. 45, 617-23.

Hulsman K. (1977) Daily attendance of terns and gulls at One Tree Island. Sunbird 8, 9-19.

Jones J. B., Hyatt A. D., Hine P. M., Whittington R. J., Griffin D. A. \& Bax N. J. (1997) Special topic review: Australasian pilchard mortalities. World J. Microbiol. Biotechnol. 13, 38392.

Kailola P. J., Williams M. J., Stewart P. C., Reichelt R. E., McNee A. \& Grieve C. (1993) Australian Fisheries Resources. Fisheries Research and Development Corporation, Canberra.

Kimmerer W. J. (2006) Response of anchovies dampens effects of the invasive bivalve Corbula amurensis on the San Francisco Estuary foodweb. Mar. Ecol.Prog. Ser. 324, 207-18.

Klasing K. C. (1998) Comparative Avian Nutrition. CAB International, Wallingford.

Klomp N. I. \& Wooller R. D. (1988) Diet of little penguin, Eudyptula minor, from Penguin Island, Western Australia. Aust. J. Mar. Freshwater Res. 39, 633-9.

Lack D. (1968) Ecological Adaptations for Breeding in Birds. Methuen \& Co Ltd, London.

McCutcheon C., Dann P., Salton M. et al. (2011) The foraging range of little penguins (Eudyptula minor) during winter. Emu doi: 10.1071/MU10078.
Mketsu Q. K. (2008) Comparative dietary analysis of small pelagic fishes from presumed mixed shoals off Souht Africa's East Coast (MSc Thesis). University of Cape Town, Cape Town.

Montague T. L. \& Cullen J. M. (1988) The diet of the little penguin Eudyptula minor at Phillip Island, Victoria. Eтu 88, 139-49.

Mortimer L. \& Lill A. (2007) Activity-related variation in blood parameters associated with oxygen transport and chronic stress in little penguins. Aust. J. Zool. 55, 249-56.

Navarro J., Forero M. G., González-Solís J., Igual J. M., Bécares J. \& Hobson K. A. (2009) Foraging segregation between two closely related shearwaters breeding in sympatry. Biol. Lett. 5, 545-8.

Newman S. H., Piatt J. F. \& White J. (1997) Hematological and plasma biochemical reference ranges of Alaskan seabirds: their ecological significance and clinical importance. Colon Waterbirds 20, 492-504.

Preston T. J. (2011) Relationships between foraging behaviour, diet and reproductive success at an urban colony of little penguins (Eudyptula minor), St Kilda, Australia. School of Biological Sciences, Monash Universtiy, Melbourne.

Preston T. J., Ropert-Coudert Y., Kato A. et al. (2008) Foraging behaviour of little penguins Eudyptula minor in an artificially modified environment. Endangered Species Res. 4, 95-103.

Preston T. J., Chiaradia A., Caarels S. A. \& Reina R. D. (2010) Fine scale biologging of an inshore marine animal. J. Exp. Mar. Bio. Ecol. 390, 196-202.

R Development Core Team (2009) R: a language and environment for statistical computing. [Cited 7 November 2011.] Available from URL: http://www.R-project.org.

Schreiber E. A. \& Burger J. (2001) Seabird in the marine environment. In: Biology of Marine Birds (eds E. A. Schreiber \& J. Burger) pp. 1-15. CRC Press, Boca Raton.

Shealer D. A. (2001) Foraging behavior and food of seabirds. In: Biology of Marine Birds (eds E. A. Schreiber \& J. Burger) pp. 137-77. CRC Press, Boca Raton.

van der Lingen C. D., Bertrand A., Bode A. et al. (2009) Trophic dynamics. In: Climate Change and Small Pelagic Fish (eds D. Checkley, J. Alheit, Y. Oozeki \& C. Roy) pp. 112-57. Cambridge University Press, Cambridge.

Ward T. M., Kinloch M., Jones G. K. \& Neira F. J. (1998) A collaborative investigation of the usage and stock assessment of baitfish and eastern Australian waters, with special reference to Pilchards Sardinops sagax. South Australian Research and Development Institute.

Weavers B.W. (1992) Seasonal foraging ranges and travels at sea of little penguins, determined by radio-tracking. Етu 91, 302-17.

Weller D. (2007) Inter-colony movements of the crested tern (Thalasseus bergii) as result of food resource quality and availability (Honour Thesis). Zoology Department, University of Melbourne, Melbourne.

Work T. M. (1996) Weights, hematology, and serum chemistry of seven species of free-ranging tropical pelagic seabirds. J.Wildl. Dis. 32, 643-57.

Zuur A. F., Ieno E. N., Walker N. J., Saveliev A. A. \& Smith G. M. (2009) Mixed Effects Models and Extensions in Ecology with $R$. Springer, New York.

\section{SUPPORTING INFORMATION}

Additional Supporting Information may be found in the online version of this article:

Appendix S1. Diet composition of little penguins. 